\title{
THE COMPARATIVE ANALYSIS OF THE ISO 9001:2015 STANDARD AND Good Clinical Practice GUIDELINES: THE FRAMEWORK FOR IMPROVING MANAGEMENT OF CLINICAL TRIALS
}

The principal concept of the ICH Q8, Q9 and Q10 guidelines is to encourage implementation of scientific and systematic approaches for quality assurance of pharmaceutical products. Clinical trials, which are the crucially important part of the pharmaceutical research and development process, are outside of these guidelines, and it actualizes the issue on introducing quality management into clinical trials.

Aim. To analyze the ISO 9001 quality management methodology and the Addendum to GCP requirements in order to elaborate the methodical background for its combined use that will provide the effective work of the quality management system while achieving GCP compliance.

Materials and methods. The methods of the comparative analysis, synthesis, generalization, abstraction and content analysis were used to determine the possibility of ISO 9001:2015 and ICH GCP integration.

Results. The Addendum to GCP demonstrates the conformity of its provisions with prominent trends of quality management confirmed by the ISO 9001:2015 standard. The Addendum to GCP declares that the quality management system should use a risk-based approach, which allows conducting clinical trials more efficiently.

Conclusions. The ICH GCP framework can be easily and effectively integrated into the ISO 9001 quality management system of a particular clinical study, as well as in the entire system of quality assurance during the drug lifecycle. Further studies should be focused on development of the practical approaches and methods for implementation of the riskbased quality management in clinical trials.

Key words: clinical trials; quality management; risk management; good clinical practice; international standard organization

\section{В. Є. Доброва, К. Л. Ратушна, Є. Ф. Грінцов, Н. П. Безугла \\ Національний фармацевтичний університет}

Порівняльний аналіз стандарту ISO 9001:2015 та Настанови з належної клінічної практики: базис для удосконалення управління клінічними випробуваннями

Принциповою концепцією керівництв ICH Q8, Q9 та Q10 є сприяння впровадженню наукового та систематичного підходів до забезпечення якості лікарських засобів. Клінічні випробування, які становлять надзвичайно важливу частину процесу фармацевтичного дослідження та розробки, знаходяться за межами цих керівництв, що робить актуальним питання щодо впровадження управління якістю у клінічні випробування.

Тому метою роботи є проведення аналізу методології управління якістю, наведеної у стандартах ISO 9001 та вимогах Доповнення до керівництва з Належної клінічної практики, що є необхідним для створення методичного підгрунтя для їх узгодженого використання та забезпечення ефективної роботи системи управління якістю одночасно з досягненням відповідності вимогам GCP.

Матеріали та методи. Методи порівняльного аналізу, синтезу, генералізації, абстракції та контент-аналізу були використані для визначення можливості інтеграції ISO 9001:2015 та ICH GCP.

Результати. Аналіз положень доповнення до GCP свідчить про його узгодженість з провідними трендами управління якістю, закріпленими у стандарті ISO 9001:2015. Також оновлена версія GCP встановлює, що система управління якістю повинна використовувати ризик-орієнтований підхід, що дозволить більш ефективно проводити клінічні випробування.

Висновки. Методологія ICH GCP може бути ефективно та без ускладнень інтегрована як у систему управління якістю ISO 9001 окремого дослідження, так і в загальну систему забезпечення якості лікарського засобу, яка охоплює весь його життєвий цикл. Подальші дослідження будуть спрямовані на розробку практичних підходів та методик для імплементації ризик-орієнтованого менеджменту в клінічних випробуваннях.

Ключові слова: клінічне випробування; управління якістю; управління ризиками; GCP; ISO 


\section{В. Е. Доброва, К. Л. Ратушная, Е. Ф. Гринцов, Н. П. Безуглая \\ Национальный фармацевтический университет

\begin{abstract}
Сравнительный анализ стандарта ISO 9001:2015 и Руководства по надлежащей клинической практике: базис для усовершенствования управления клиническими исследованиями
\end{abstract}

Актуальность. Принципиальной концепцией руководств ICH Q8, Q9 и Q10 является способствование внедрению научного и систематического подходов к обеспечению качества лекарственных средств. Клинические исследования, которые составляют чрезвычайно важную часть процесса фармацевтического исследования и разработки, находятся вне сферы данных руководств, что делает актуальным вопрос о внедрении управления качеством в клинические исследования.

Поэтому целью работы является проведение анализа методологии управления качеством, приведенной в стандарте ISO 9001? и требований Дополнения к руководству Надлежащей клинической практики, что является необходимым для создания методического основания для их согласованного использования и обеспечения эффективной работы системы управления качеством одновременно с достижением соответствия требованиям GCP.

Материалы и методы. Методы сравнительного анализа, синтеза, генерализации, абстракции и контент-анализа были использованы для определения возможности интеграции ISO 9001:2015 и ICH GCP.

Результаты и обсуждение. Анализ положений дополнения к GCP свидетельствует о его согласованности с передовыми трендами управления качеством, закрепленными в стандарте ISO 9001:2015. Также обновленная версия GCP устанавливает, что система управления качеством должна использовать риск-ориентированный подход, что позволит более эффективно проводить клинические исследования.

Выводы. Методология ICH GCP может эффективно и без затруднений быть интегрирована как в систему управления качеством ISO 9001 отдельного исследования, так и в общую систему обеспечения качества лекарственного средства, которая охватывает весь его жизненный цикл. Последующие исследования будут ориентированы на разработку практических подходов и методик для имплементации риск-ориентированного менеджмента в клинических исследованиях.

Ключевые слова: клиническое исследование; управление качеством; управление рисками; GCP; ISO

$\mathrm{N}^{\mathrm{e}}$ ew challenges in the field of medical research lead to transformation of the basic approaches for quality assurance of pharmaceutical products. Introduction of the ICH Q8, Q9 and Q10 Guidelines allows building a unified sciencebased system, which covers the entire product lifecycle and is intended to improve the drug quality and efficiency of pharmaceutical manufacturing $[1,2]$. The principal concept of these guidelines is to encourage implementation of scientific and systematic approaches for quality assurance of pharmaceutical products $[3,4]$. It is widely acknowledged that clinical trials are the crucially important part of the pharmaceutical research and development process [5, $6]$. But, they are outside the scope of these guidelines $[1,4,7]$.

Nevertheless, the quality of the clinical development is an important issue since it provides scientific evidences about the principal properties of the drug quality - safety and efficiency $[3,6,8]$. Thus, the quality of the clinical stage of the drug development should be assured at the appropriate level in order to contribute to the entire quality system of pharmaceutical products $[1,9,10]$.

The fundamental framework for providing quality by any organization is described in the ISO 9001 standard [11]. After 2015 revision of the ISO standard the risk-based approach was included into the quality management system. These changes were encouraged by the modern conditions related to the lack of resources, as well as simultaneous arising of the quality demands, and reflect the need for the efficiency increase $[1,4,11]$.

The basic industry standard for performing clinical trials is Good Clinical Practice Guideline (GCP), which contains the requirements to study quality and perform its processes [12]. Following the riskbased innovative approaches and considering the existence of the pharmacy industry guideline for the Quality Risk Management ICH Q9 the GCP framework was also reviewed concerning the quality system, introduction of risk-based approaches and electronic data management $[1,3,4,8]$. The first question arising while implementing quality management into clinical drug trials (CDT) is the possibility of the combined use of ISO 9001:2015 and GCP, as well as conformity of their requirements.

Thus, the aim of our study is a detail analysis and comparison of the ISO 9001:2015 quality management methodology and GCP requirements in order to elaborate the methodical background in the context of its consistent integration for enhancing of the clinical trials system.

\section{Materials and methods}

In order to examine the conformity of the ISO 9001:2015 and the Integrated Addendum to ICH E6 (R1) the comparative analysis of these documents was performed. Conclusions and recommendations concerning integration of the GCP framework 
into the ISO 9001:2015 quality management system were formulated using the methods of synthesis, generalization, abstraction and content-analysis.

\section{Results and discussion}

The Addendum to ICH E6 (R1): Guideline for Good Clinical Practice E6 (R2) contains critically important aspects and a fundamentally new approach relating to the quality management system within the clinical research [12]. Thus, a new version of GCP obliges the sponsor to implement the quality management throughout all stages of the clinical trial, including design, conduct, recording, evaluation, reporting and archiving of clinical trials. One of the main ideas of the new approach is proportionality of the methods used to assure and control the quality of the trial to risks inherent in the trial and the importance of the information collected.
To enhance implementation of the quality management standards into routine practice of clinical trials the analysis of particular paragraphs of the international standard ISO 9001:2015 and GCP provisions regarding the sponsor's and investigator's activities for the CDT quality assurance was conducted (Tab.). This comparison allows us to design the strategy of ISO requirements into the investigator's activities, as well as the sponsor's ones, and choose the strategy how to remove the main existing gaps for implementing the ISO 9001:2015 oriented management into the CDT practice $[2,4]$.

Such analysis helps to reveal specificity in performing the quality management functions by investigators and the sponsor. It also substantiates the importance of the quality management system building at a trial site since an independent structure is focused on specific goals that represent needs and expectations of stakeholders interacting

Table

\section{The comparative analysis of the ISO 9001:2015 and the Integrated Addendum to ICH E6(R1): Guideline for Good Clinical Practice E6 (R2) concerning clinical trial quality management}

\begin{tabular}{|c|c|c|}
\hline \multirow{2}{*}{ ISO 9001:2015 } & \multicolumn{2}{|c|}{ Addendum to the ICH E6(R1) paragraph concerning to } \\
\hline & The Sponsor's Activity & The Investigator's Activity \\
\hline 1 & 2 & 3 \\
\hline $\begin{array}{l}\text { 4.4 Quality mana- } \\
\text { gement system } \\
\text { and its processes }\end{array}$ & $\begin{array}{l}\text { 5.0 Quality Management } \\
\text { The sponsor should implement a system } \\
\text { to manage quality throughout the design, } \\
\text { conduct, recording, evaluation, reporting and } \\
\text { archiving of clinical trials. } \\
\text { Sponsors should focus on the trial activities } \\
\text { that are essential to ensuring the human } \\
\text { subject protection and the reliability of trial } \\
\text { results. Quality management includes the } \\
\text { efficient design of clinical trial protocols, data } \\
\text { collection tools and procedures, as well as the } \\
\text { collection of information that is essential to } \\
\text { decision making. } \\
\text { The methods used to assure and control the } \\
\text { quality of the trial should be proportionate to } \\
\text { the risks inherent in the trial and the impor- } \\
\text { tance of the information collected. The spon- } \\
\text { sor should ensure that all aspects of the trial } \\
\text { are operationally feasible and should avoid } \\
\text { unnecessary complexity, procedures and data } \\
\text { collection. Protocols, case report forms, and } \\
\text { other operational documents should be clear, } \\
\text { concise and consistent. } \\
\text { 5.1.1 The sponsor is responsible for imple- } \\
\text { menting and maintaining the quality assur- } \\
\text { ance and the quality control systems with } \\
\text { written SOPs to ensure that trials are con- } \\
\text { ducted and data are generated, documented } \\
\text { (recorded), and reported in compliance with } \\
\text { the protocol, GCP, and the applicable regula- } \\
\text { tory requirement(s) }\end{array}$ & $\begin{array}{l}\text { 4.1.3 The investigator should be aware of, and } \\
\text { should comply with, GCP and the applicable } \\
\text { regulatory requirements }\end{array}$ \\
\hline
\end{tabular}




\begin{tabular}{|c|c|c|}
\hline 1 & 2 & 3 \\
\hline $\begin{array}{l}\text { 5.3 Organizational } \\
\text { roles, responsibili- } \\
\text { ties and authori- } \\
\text { ties }\end{array}$ & $\begin{array}{l}\text { 5.7 Responsibilities } \\
\text { Prior to initiating a trial the sponsor should } \\
\text { define, establish, and assign all trial-related } \\
\text { duties and functions. } \\
\text { The sponsor is responsible for securing agree- } \\
\text { ment from all involved parties to ensure direct } \\
\text { access to all trial related sites, the source data/ } \\
\text { documents, and reports for the purpose of } \\
\text { monitoring and auditing by the sponsor, and } \\
\text { inspection by domestic and foreign regulatory } \\
\text { authorities }\end{array}$ & $\begin{array}{l}\text { 4.1.5 The investigator should maintain a list of } \\
\text { appropriately qualified persons to whom the } \\
\text { investigator has delegated significant trial- } \\
\text { related duties. } \\
\text { 4.2.5 The investigator is responsible for super- } \\
\text { vising any individual or party to whom the } \\
\text { investigator delegates study tasks conducted } \\
\text { at the trial site. } \\
4.2 .6 \text { If the investigator/institution retains the } \\
\text { services of any party to perform study tasks } \\
\text { they should ensure this party is qualified to } \\
\text { perform those study tasks and should imple- } \\
\text { ment procedures to ensure the integrity of the } \\
\text { study tasks performed and any data generated }\end{array}$ \\
\hline 7.1.2 People & $\begin{array}{l}\text { 5.4.1 The sponsor should employ qualified } \\
\text { individuals (e.g., biostatisticians, clinical phar- } \\
\text { macologists, and physicians) as appropriate, } \\
\text { throughout all stages of the trial process, from } \\
\text { designing the protocol and CRFs and plan- } \\
\text { ning the analyses to analyzing and preparing } \\
\text { interim and the final clinical trial reports } \\
\end{array}$ & $\begin{array}{l}\text { 4.2.4 The investigator should ensure that all } \\
\text { persons assisting with the trial are adequately } \\
\text { informed about the protocol, the investiga- } \\
\text { tional product(s), and their trial-related duties } \\
\text { and functions }\end{array}$ \\
\hline 7.1.3 Infrastructure & $\begin{array}{l}\text { 5.6.1 The sponsor is responsible for selecting } \\
\text { the investigator(s)/ institution(s). Each investi- } \\
\text { gator should be qualified by training and ex- } \\
\text { perience and should have adequate resources } \\
\text { to properly conduct the trial for which the } \\
\text { investigator is selected. If organization of a co- } \\
\text { ordinating committee and/or selection of a co- } \\
\text { ordinating investigator(s) are to be employed } \\
\text { in multicentre trials, their organization and/or } \\
\text { selection are the sponsor's responsibility }\end{array}$ & $\begin{array}{l}\text { 4.2.1 The investigator should be able to dem- } \\
\text { onstrate (e.g., based on retrospective data) a } \\
\text { potential for recruiting the required number } \\
\text { of suitable subjects within the recruitment } \\
\text { period agreed. } \\
\text { 4.2.3 The investigator should have available } \\
\text { an adequate number of qualified staff and } \\
\text { adequate facilities for the foreseen duration } \\
\text { of the trial to conduct the trial properly and } \\
\text { safely }\end{array}$ \\
\hline 7.2 Competence & $\begin{array}{l}\text { 5.3 Medical Expertise } \\
\text { The sponsor should designate the appropri- } \\
\text { ately qualified medical personnel who will be } \\
\text { readily available to advise on the trial related } \\
\text { medical questions or problems. If necessary, } \\
\text { outside consultant(s) may be appointed for } \\
\text { this purpose }\end{array}$ & $\begin{array}{l}\text { 4.1.1 The investigator(s) should be qualified } \\
\text { by education, training, and experience to } \\
\text { assume responsibility for the proper conduct } \\
\text { of the trial, should meet all the qualifica- } \\
\text { tions specified by the applicable regulatory } \\
\text { requirement(s), and should provide evidence } \\
\text { of such qualifications through up-to-date cur- } \\
\text { riculum vitae and/or other relevant documen- } \\
\text { tation requested by the sponsor, the IRB/IEC, } \\
\text { and/or the regulatory authority(ies) }\end{array}$ \\
\hline $\begin{array}{l}\text { 7.5.3 Control of } \\
\text { the documented } \\
\text { information }\end{array}$ & $\begin{array}{l}\text { 5.15.1 The sponsor should ensure that it } \\
\text { is specified in the protocol or other writ- } \\
\text { ten agreement that the investigator(s)/ } \\
\text { institution(s) provide direct access to source } \\
\text { data/documents for trial-related monitoring, } \\
\text { audits, IRB/IEC review, and regulatory inspec- } \\
\text { tion }\end{array}$ & $\begin{array}{l}\text { 4.9.0 The investigator should maintain ad- } \\
\text { equate and accurate source documents and } \\
\text { trial records that include all pertinent observa- } \\
\text { tions on each of the site's trial subjects. The } \\
\text { source data should be attributable, legible, } \\
\text { contemporaneous, original, accurate, and } \\
\text { complete. Changes to the source data should } \\
\text { be traceable, should not obscure the original } \\
\text { entry and should be explained if necessary } \\
\text { (e.g., via an audit trail) }\end{array}$ \\
\hline
\end{tabular}




\begin{tabular}{|l|l|l|}
\hline \multicolumn{1}{|c|}{1} & \multicolumn{1}{|c|}{2} & \multicolumn{1}{|c|}{3} \\
\hline $\begin{array}{l}\text { 9.1 Monitoring, } \\
\text { measurement, } \\
\text { analysis and evalu- } \\
\text { ation }\end{array}$ & $\begin{array}{l}\text { 5.5.2 The sponsor may consider establishing } \\
\text { an independent data-monitoring committee } \\
\text { (IDMC) to assess the progress of a clinical trial, } \\
\text { including the safety data and the critical effica- } \\
\text { cy endpoints at intervals, and to recommend } \\
\text { to the sponsor whether to continue, modify, } \\
\text { or stop a trial. The IDMC should have written } \\
\text { operating procedures and maintain written } \\
\text { records of all its meetings. }\end{array}$ & $\begin{array}{l}\text { 4.1.4 The investigator/institution should per- } \\
\text { mit monitoring and auditing by the sponsor, } \\
\text { and inspection by the appropriate regulatory } \\
\text { authority }\end{array}$ \\
& $\begin{array}{l}\text { 5.18 Monitoring. } \\
\text { 5.18.1 Purpose. } \\
\text { 1099 The purposes of the trial monitoring are } \\
\text { to verify that: (a) The rights and well-being of } \\
\text { human subjects are protected. } \\
\text { (b) The reported trial data are accurate, com- } \\
\text { plete, and verifiable from source documents. } \\
\text { (c) The conduct of the trial is in compli- } \\
\text { ance with the currently approved protocol/ } \\
\text { amendment(s), with GCP, and with the appli- } \\
\text { cable regulatory requirement(s) }\end{array}$ & \\
\hline
\end{tabular}

during clinical trials while assuring high coordination and efficacy of the interaction.

In this way, the quality management system at a trial site, which is an important element of the clinical stage of drug development, can be easily integrated into the entire system of quality assurance that embraces all stages of the drug lifecycle $[1,3]$.

It should be underlined that 2015 version of the ISO standard contains an idea of risk-based thinking [11]. Thus, the risk assessment became an important part of planning the quality management system [4]. As a result, the preventive actions were replaced by actions to address risks and opportunities. In practical context this transforms the reactive quality management style to the pro-active one.

The implementation of this innovative approach by a new version of GCP elaborated in accordance with the ICH Q9 Guideline will allow applying the "improved and more efficient approaches to the clinical trial design, conduct, oversight, recording and reporting while continuing to ensure the human subject protection and data integrity". The ICH GCP declares that the quality management system, which uses a risk-based approach, should have the following structure: 1) critical process and data identification, 2) risk identification, 3) risk evaluation, 4) risk control, 5) risk communication, 6) risk review, and 7) risk reporting [12].

Focus on risks described in detail in the Addendum to GCP demonstrates the conformity of its provisions with prominent trends of quality management set by the ISO 9001:2015 standard. The relevance of these issues encourages scholars and practitioners in the field of clinical trials to study the aspects of the risk-based management and quality assurance in clinical research and develop the corresponding knowledge-based methodical approaches.

\section{CONCLUSIONS}

The analysis has shown that the Integrated Addendum to ICH GCP E6 (R1) reflects all fundamental principles of quality management declared by ISO 9001:2015. That will provide the consistency between the revised version of GCP and ISO 9001:2015. After reviewing of GCP it can be easily and effectively integrated into the ISO 9001 quality management system due to the additional paragraph that describes the quality system development.

This initiates the new stage of clinical trial quality assurance built on modern concepts of quality management, and it is encompasses the risk-based approach. Thus, at the next stage the practical approaches and methods targeted on implementation of the risk-based quality management in clinical trials should be scientifically substantiated and elaborated. In our opinion, the special attention should be paid to description of the role of an investigator and a trial site within the whole quality management system of clinical trials and, particularly, at the stage of risk assessment and treatment.

Conflicts of Interests: authors have no conflict of interests to declare. 


\section{References}

1. Зупанець, К. О. Наукове обгрунтування інтегрованої системи управління клінічним випробуванням лікарських засобів на місці проведення дослідження / К. О. Зупанець, В. Є. Доброва, О. М. Проскурня // Управління, економіка та забезпечення якості в фармації. - 2015. - Вип. 4 (42). - С. 60-66.

2. Зупанець, К. О. Аналіз думки фахівців щодо впровадження концептуальних положень управління ризиками у клінічні дослідження лікарських засобів / К. О. Зупанець, В. Є. Доброва // Запорожский мед. журн. - 2016. - № 3 (96). - С. 93-98.

3. Zupanets, K. O. Process model of the trial site quality management system / K. O. Zupanets, V. Ye. Dobrova // Asian J. of Pharmac. and Clin. Res. - 2016. - Vol. 9, Issue 3. - P. 225-228.

4. Зупанець, К. О. Концептуальні положення щодо управління ризиками у клінічному випробуванні лікарського засобу на місці проведення дослідження / К. О. Зупанець, В. Є. Доброва // Управління, економіка та забезпечення якості в фармації. - 2015.- № 6 (44). - С. 49-57.

5. Current trends in globalization of industry-sponsored clinical trials / V. Misik, R. V. Brady, M. Bolecel et al. // Applied Clin. Res., Clinical Trials \& Regulatory Affairs. - 2014. - Vol. 1, Issue 1. - P. 56-66. doi: 10.2174/2213476x01666131111191016

6. Доброва, В. Є. Обгрунтування та розробка лінійної моделі спостережень при клінічних випробуваннях / В. Є. Доброва, I. А. Зупанець // Клінічна фармація. - 2012. - Т. 16, № 1. - С. 18-21.

7. Enhancing clinical evidence by proactively building quality into clinical trials / A. Meeker-0'Connel, C. Glessner, M. Behm et al. // Clinical Trials. - 2016. - Vol. 13, Issue 4. - P. 439-444. doi: 10.1177/1740774516643491

8. Дослідження аспектів управління ризиками втрати якості даних при клінічному випробуванні / К. Л. Ратушна, К. О. Зупанець, В. Є. Доброва, О. М. Котенко // Управління, економіка та забезпечення якості в фармації. - 2013.- № 5 (31). - C. $16-23$.

9. Доброва, В. Є. Наукове обгрунтування ролі стандартних операційних процедур у системі забезпечення якості клінічного випробування лікарських засобів / В. Є. Доброва, К. О. Зупанець, К. Л. Ратушна // Управління, економіка та забезпечення якості в фармації. - 2013. - № 1 (27). - С. 23-28.

10. Scientific and practical substantiation of ways of developing and introducing electronic case report forms to ensure the quality of bioequivalence studies / K. O. Zupanets., V. Ye. Dobrova, A. V. Zaichenko, O. V. Dorovskyi // Res. and Reviews: J. of Hospital and Clinical Pharmacy. - 2015. - Vol. 1, Issue 3. - P. 21-25.

11. Quality management systems. Requirements (ISO 9001:2015). - Geneva : ISO, 2015. - 29 p.

12. Guideline for Good Clinical Practice. ICH Harmonised Guideline Integrated Addendum to ICH E6(R1) : Guideline for Good Clinical Practice E6(R2) [Електронний ресурс] // International Conference on Harmonisation of Technical Requirements for Registration of Pharmaceuticals for Human Use, 2015. - Brussel, 2015. - Available at: http://www.ich.org/fileadmin/ Public_Web_Site/ICH_Products/Guidelines/Efficacy/E6/E6_R2_Addendum_Step2.pdf

13. Risk-Adapted Monitoring in Clinical Trials. Summary Information by ECRIN (European Clinical Research Infrastructures Network) PPI WP8/monitoring. - 2011. - Available at: http://www.ecrin.org/fileadmin/user_upload/public_documents/ News/Activities/ECRIN_proposal_monitoring_final_28012013-1.pdf

14. Guideline for Industry. Oversight of Clinical Investigations. A Risk-Based Approach to Monitoring. Draft Guidance / Food and Drug Administration. - N.-Y. : FDA, 2011. - 41 p.

15. Risk-adapted approaches to the management of clinical trials of investigational medicinal products. - Available at: http:// www.mhra.gov.uk/Howweregulate/Medicines/Licensingofmedicines/Clinicaltrials/index.html

\section{References}

1. Zupanets, K. O., Dobrova, V. Ye., Proskurnia, O. M. (2015). Upravlinnia, ekonomika ta zabezpechennia yakosti v farmatsii, 4 (42), 60-66.

2. Zupanets, K. O., Dobrova, V. Ye. (2016). Zaporozhskii medytcynskii zhurnal, 3 (96), 93-98.

3. Zupanets, K. O., Dobrova, V. Ye. (2016). Process model of the trial site quality management system. Asian Journal of Pharmaceutical and Clinical Research, 9 (3), 225-228.

4. Zupanets, K. O., Dobrova, V. Ye. (2016). Upravlinnia, ekonomika ta zabezpechennia yakosti v farmatsii, 6 (44), 49 - 57.

5. Misik, V., V. Brady, R., Bolecek, M., Klech, H. (2014). Current Trends in Globalization of Industry-Sponsored Clinical Trials. Applied Clinical Research, Clinical Trials and Regulatory Affairs, 1 (1), 56-66. doi: 10.2174/2213476x01666131111191016

6. Dobrova, V. Ye., Zupanets, I. A. (2012). Klinichna farmatsiia - Clinical Pharmacy, 16 (1), 18-21.

7. Meeker-O'Connell, A., Glessner, C., Behm, M., Mulinde, J., Roach, N., Sweeney, F., Landray, M. J. (2016). Enhancing clinical evidence by proactively building quality into clinical trials. Clinical Trials, 13 (4), 439-444. doi: 10.1177/1740774516643491

8. Ratushna, K. L., Zupanets, K. O., Dobrova, V. Ye., Kotenko, O. M. (2013). Upravlinnia, ekonomika ta zabezpechennia yakosti v farmatsii, 5 (31), 16 - 23.

9. Dobrova, V. Ye., Zupanets, K. O., Ratushna, K. L. (2013). Upravlinnia, ekonomika ta zabezpechennia yakosti v farmatsii, 1 (27), 23-28.

10. Zupanets., K. O., Dobrova, V. Ye., Zaichenko, A. V., Dorovskyi, O. V. (2015). Scientific and practical substantiation of ways of developing and introducing electronic case report forms to ensure the quality of bioequivalence studies. Research and Reviews: Journal of Hospital and Clinical Pharmacy, 1 (3), 21-25.

11. Quality management systems. Requirements (ISO 9001:2015). (2015). Geneva: ISO, 29.

12. Guideline for Good Clinical Practice. ICH Harmonised Guideline Integrated Addendum to ICH E6(R1): Guideline for Good Clinical Practice E6(R2) (2015). International Conference on Harmonisation of Technical Requirements for Registration of Pharmaceuticals for Human Use. Brussel. Available at: http://www.ich.org/fileadmin/Public_Web_Site/ICH_Products/Guidelines/ Efficacy/E6/E6_R2_Addendum_Step2.pdf

13. Risk-Adapted Monitoring in Clinical Trials. Summary Information by ECRIN (European Clinical Research Infrastructures Net- 
work) PPI WP8/monitoring (2011). Available at: http://www.ecrin.org/fileadmin/user_upload/public_documents/News/ Activities/ECRIN_proposal_monitoring_final_28012013-1.pdf

14. Guideline for Industry. Oversight of Clinical Investigations. A Risk-Based Approach to Monitoring. Draft Guidance. (2011). Food and Drug Administration. N.-Y.: FDA, 41.

15. Risk-adapted approaches to the management of clinical trials of investigational medicinal products. Available at: http://www. mhra.gov.uk/Howweregulate/Medicines/Licensingofmedicines/Clinicaltrials/index.html

Information about authors / Відомості про авторів / Информация об авторах

Dobrova V. Ye., Doctor of Pharmacy (Dr. habil.), professor of the Clinical Pharmacology and Clinical Pharmacy Department, National University of Pharmacy

Доброва B. $\boldsymbol{\epsilon}$., доктор фармацевтичних наук, професор кафедри клінічної фармакології та клінічної фармації, Національний фармацевтичний університет

Доброва B. E., доктор фармацевтических наук, профессор кафедры клинической фармакологии и клинической фармации,

Национальный фармацевтический университет

Ratushna K. L., Candidate of Pharmacy (Ph.D.), teaching assistant of the Clinical Pharmacology and Clinical Pharmacy Department, National University of Pharmacy

Ратушна К. Л., кандидат фармацевтичних наук, асистент кафедри клінічної фармакології та клінічної фармації, Національний фармацевтичний університет

Ратушная К. Л., кандидат фармацевтических наук, ассистент кафедры клинической фармакологии и клинической фармации, Национальный фармацевтический университет

Grintsov Ie. F., Candidate of Medicine (Ph.D.), associate professor of the Clinical Pharmacology and Clinical Pharmacy Department, National University of Pharmacy

Грінцов $\boldsymbol{\epsilon}$. Ф., кандидат медичних наук, доцент кафедри клінічної фармакології та клінічної фармації, Національний фармацевтичний університет

Гринцов $\boldsymbol{E}$. Ф., кандидат медицинских наук, доцент кафедры клинической фармакологии и клинической фармации, Национальный фармацевтический университет

Bezugla N. P., Candidate of Medicine (Ph.D.), associate professor of the Clinical Pharmacology and Clinical Pharmacy Department, National University of Pharmacy

Безугла Н. П., кандидат медичних наук, доцент кафедри клінічної фармакології та клінічної фармації, Національний фармацевтичний університет

Безуглая Н. П., кандидат медицинских наук, доцент кафедры клинической фармакологии и клинической фармации, Национальный фармацевтический университет

Mailing address: 27, Pushkinskaya str., Kharkiv, 61057, Clinical Pharmacology and Clinical Pharmacy Department, National University of Pharmacy. +38 05770630 72. E-mail: clinpharm@nuph.edu.ua

Адреса для листування: 61057, м. Харків, вул. Пушкінська, 27, кафедра клінічної фармакології та клінічної фармації НФаУ.

+38057 70630 72. E-mail: clinpharm@nuph.edu.ua

Адрес для переписки: 61057, г. Харьков, ул. Пушкинская, 27, кафедра клинической фармакологии и клинической фармации НФаУ. +38057 70630 72. E-mail: clinpharm@nuph.edu.ua 